\title{
SISTEM INFORMASI PENGAWASAN DAN KONSERVASI PENYU DI BALAI KONSERVASI PESISIR PANTAI PANGUMBAHAN KABUPATEN SUKABUMI
}

\author{
Rusda Wajhillah, Agung Wibowo \\ STMIK Nusa Mandiri Sukabumi \\ Jl. Veteran II No.20A Kota Sukabumi, 43111, Indonesia \\ Rusda.rwh@nusamandiri.ac.id
}

\begin{abstract}
Abstrak - Penyu merupakan hewan dilindungi dan terancam punah (endangered spesies). Terpeliharanya wilayah pesisir pantai pangumbahan sukabumi agar selalu terjaga dengan baik, tidak langsung mendukung populasi penyu dan habitatnya. Permasalahan yang dihadapi saat ini dari sisi geografis adalah jarak (206 Kilometer) dan waktu tempuh (sekitar 8 jam) yang dibutuhkan setiap pelaporan pengelolaan konservasi penyu pantai Pangumbahan Kabupaten Sukabumi. Penelitian ini bertujuan untuk membangun sistem informasi konservasi dan pengawasan penyu di balai konservasi Pesisir Pantai Pangumbahan kab.Sukabumi berbasis web dan menerapkan aplikasi pelaporan berbasis android untuk petugas pemantau. Sistem informasi ini menerapkan pengukuran kualits perangkat lunak dalam COBIT untuk mendukung tatakelola dari penerapan teknologi informasinya. Data hasil pengolahan nilai kuesiner dapat disimpulkan bahwa nilai bobot aplikasi android sipenyu lebih unggul 3.2 poin (31.8-21.6) dan selisih nilai 21.4 poin dari total nilai dari keseluruhan faktor penilaian kualitas perangkat lunak. Manfaat langsung dari aplikasi pengawasan ini adalah mudahnya petugas konservasi dalam menginput data penyu yang mendarat dan penyu yang bertelur dari masing-masing petugas pos sesuai dengan kondisi sebenarnya.
\end{abstract}

Keywords - Kualitas Perangkat Lunak, COBIT, Sistem Informasi.

\section{PENDAHULUAN}

Penyu merupakan satwa liar dilindungi, dengan dengan status keberadaannya terancam punah (endangered spesies). Dari enam spesies penyu yang terdapat di Indonesia yaitu penyu belimbing, penyu sisik, penyu lekang, penyu tempayan, penyu pipih, saat inihanya penyu hijau yang mendarat dan betelur di lokasi pantai pangumbahan di kabupaten Sukabumi. Keenam penyu tersebut dilindungi Undang-Undang No. 5 tahun 1990 tentang Konservasi SDA Hayati dan Ekosistemnya beserta aturan pelaksanaan berdsarkan PERMEN No. 7 tahun 1999 tentang Pengawetan Jenis Tumbuhan dan Satwa [1]. Pantai Pengumbahan Sukabumi merupakan pantai peneluruan yang paling produktif sebagai lokasi peneluran penyu hijau (chelonia mydas) di pulau Jawa. Terpeliharanya wilayah pesisir pantai kabupaten sukabumi berbatasan langsung dengan samudera Indonesia yang juga merupakan menjadi sumber kehidupan bagi 12.400 nelayan disana sangat perlu dijaga [2].

Keberadaan wilayah pantai yang terjaga secara tidak langsung akan mendukung keberadaan koservasi penyu dan mencegah terjadinya kepunahan penyu hijau di Indonesia. Tahun 2016 pengelolaan Taman Pesisir Pantai Penyu Pangumbahan harus diambil alih oleh Pemrov. Jawa Barat melalui SK Menteri Kelautan Nomor 5/KEPMEN-KP/2016 tanggal 5 Februari 2016 Tentang Kawasan Konservasi Pesisir dan Pulau-Pulau Kecil Pantai Penyu Pangumbahan dan Perairan Sekitarnya Di Kabupaten Sukabumi Provinsi Jawa Barat.
KEPMEN ini berisi Pengawasan dan Pengendalian (wasdal) terhadap sumber daya penyu perlu dilakukan untuk menjamin terselenggaranya wasdal sumber daya secara berdaya dan berhasil guna, perlu dilakukan wasdal terhadap pelaksanaannya. Terutama dalam hal pengawasan penangkapan dan pengambilan telur yang belum memadai. Hal ini disebabkan diantaranya oleh lokasi yang jauh, kekurangan aparat, kurang sarana prasarana pengawasan.

Akibat dari kurang efektifnya wasdal menyebabkan masih saja terjadi pemanfaatan sumber daya penyu tanpa diikuti upaya pelestariannya. Selama ini juga masih banyak lokasi pantai peneluran yang belum dijadikan kawasan konservasi alam [3]. Permasalahan geografis yang dihadapi saat ini adalah jarak (206 Kilometer) dan waktu tempuh (sekitar 8 jam) yang dibutuhkan setiap pelaporan pengelolaan konservasi ke pemrov Jawa barat. Terdapat enam pos titik pengawasan dan pemantauan konservasi penyu yang terpisah dengan lokasi penetasan dan pelepasan anak penyu (tukik) sehingga proses pengumpulan dan pelaporan datanya kurang efektif karena dilakukan secara offline sehingga terjadi penundaan pelaporan. Aplikasi android merupakan sebagian dari pemanfataan sistem operasi dalam mendukung berjalannya sebuah perangkat lunak.

Sistem informasi konservasi dan pengawasan penyu (Sipenyu) digunakan untuk mengatasi permasalahan pelaporan dan pemantauan secara daring. Control Objective for Information and Related Technology (COBIT) merupakan satu kerangka kerja yang digunakan untuk mendukung tata kelola dari penerapan teknologi informasi. Prinsip dasar dari 
COBIT memiliki prinsip dasar untuk menyediakan informasi diperlukan dalam mencapai tujuan perusahaan/organisasi.

Sumber daya teknologi di perusahaan atau organisasi perlu menggunakan sekumpulan proses teknologi informasi yang terstruktur baik sehingga akan memberikan informasi yang dibutuhkan. Berdasarkan kondisi dan permasalahan yang ada, maka penelitian ini bertujuan untuk membangun sistem informasi konservasi dan pengawasan penyu di Pusat Konservasi Penyu di kabupaten Sukabumi berbasis web dan menerapkan aplikasi android untuk pelaporan petugas pemantau. Sistem informasi ini menerapkan COBIT untuk mendukung tatakelola dari penerapan teknologi informasinya.

\section{Metodologi Penelitian}

Metode penelitian Penelitian ini dilaksanakan di penangkaran penyu Jalan Cipinang-Gunung Batu, Pangumbahan, Ciracap, Kab.Sukabumi, Jawa Barat. Teknik pengumpulan data yang digunakan adalah metode observasi dan/atau wawancara di lokasi penelitian dan kepada petugas.

Pengembangan aplikasi (perangkat lunak) yang dilakukan dalam penelitian ini menggunakan metode linear sequential model, terkadang disebut juga classic life cycle atau waterfall [2]. Model ini memaparkan model klasik yang bersifat sistematis, berurutan dalam membangun aplikasi, dengan tahapan utama sebagai berikut:

1) Tahap Sistem/Rekayasa Informasi: Metode yang digunakan saat pengumpulan data meliputi: studi pustaka, yaitu mengumpulkan data dengan cara melakukan studi, analisis dan dokumentasi literature. Sumber lainya yaitu: jurnal, dan website di internet yang berhubungan dengan permasalahan konservasi penyu dan pemanfaatan mobile computing.

2) Tahap Pengembangan Aplikasi: tahap ini dilakukan analisis desain code untuk pembangunan aplikasi, dan pengujian berupa debugging. Metodologi digunakan ini sebagai pedoman untuk mengetahui perangkat lunak yang akan digunakan dan bagaimana menggunakan perangkat lunak-perangkat lunak terkait tersebut, beserta cara pengkodeannya dan apa yang harus dikerjakan selama pengembangan sistem informasi konservasi penyu.

3) Tahap Operasi dan perawatan Analisis sistem akan melakukan pengujian tingkat kematangan sistem, perawatan dan pengembangan sistem yang telah dicapai. Ketiga tahap diatas dijabarkan dalam kerangka pemikiran pada Gbr. 1 Kerangka Pemikiran.

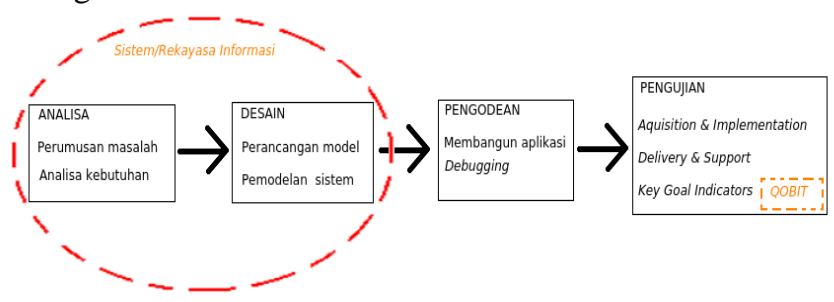

Gbr. 1 Kerangka Pemikiran
Pada penelitian ini, pembahasan juga difokuskan pada domain Monitoring and Evaluate (MaE) untuk faktor MaE IT Performance untuk pengujian kualitas perangkat lunak Pengertian kualitas adalah sejauh mana suatu sistem, komponen, atau proses memenuhi kebutuhan atau harapan pelanggan atau pengguna [5]. Daftar Faktor dan Kriteria yang terjabar pada Tabel I Faktor dan Kriteria Perangkat Lunak .

TABEL I

FACTOR DAN KRITERIA PERANGKAT LUNAK QUALITY FACTOR

\begin{tabular}{|c|c|}
\hline $\begin{array}{l}\text { Quality Factor } \\
\text { (Effect) }\end{array}$ & Quality Criteria (Cause) \\
\hline Correctness & $\begin{array}{l}\text { Completeness, } \\
\text { Traceability }\end{array}$ \\
\hline Reliability & 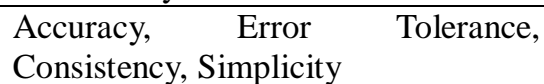 \\
\hline Efficiency & $\begin{array}{l}\text { Execution Efficiently, Storage } \\
\text { Efficiency }\end{array}$ \\
\hline Integrity & Access Control, Access Audit \\
\hline Usability & $\begin{array}{l}\text { Communicativeness, } \\
\text { Training }\end{array}$ \\
\hline Maintainability & $\begin{array}{l}\text { Consistency, Conciseness, Simplicity, } \\
\text { Modularity, Self-documentation }\end{array}$ \\
\hline Testability & $\begin{array}{l}\text { Simplicity, Modularity, } \\
\text { Instrumentation, Self-documentation }\end{array}$ \\
\hline Flexibility & $\begin{array}{l}\text { Expandability, Generality, } \\
\text { Modularity, Self-documentation }\end{array}$ \\
\hline Portability & $\begin{array}{l}\text { Software System independence, } \\
\text { Hardware Independence, Self- } \\
\text { documentation, Modularity }\end{array}$ \\
\hline Reusability & 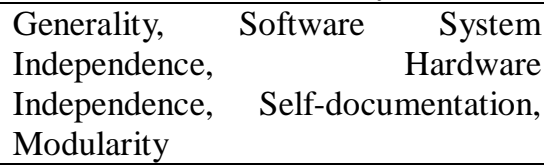 \\
\hline Interoperability & $\begin{array}{l}\text { Communication Commonality, Data } \\
\text { Commonality, Modularity }\end{array}$ \\
\hline
\end{tabular}

Sumber: [6]

Kualitas perangkat lunak diukur dengan metode penjumlahan kriteria-kriteria dalam faktor sesuai dengan bobot yang telah ditetapkan [5]. Berikut ini rumus pengukuran yang digunakan:

$$
\mathrm{Fa}=\mathrm{W} 1 \mathrm{C} 1+\mathrm{W} 2 \mathrm{C} 2+\ldots+\mathrm{WnCn}
$$

Dimana:

Fa adalah total nilai dari faktor a

Wi adalah bobot untuk kriteria i

$\mathrm{Ci}$ adalah nilai untuk kriteria i

Tahap selanjutnya yang harus dilakukan dalam pengukurannya sebagai berikut:

Tahap 1: Penentuan kriteria yang untuk mengukur suatu faktor Tahap 2: Penentuan bobot (w) dari setiap kriteria (umumnya 0 $\leq \mathrm{w} \leq 1)$ 
Tahap 3: Penentuan skala dari nilai kriteria (misalkan, $0 \leq$ nilai kriteria $\leq 10)$

Tahap 4: Penentuan nilai pada tiap kriteria

Tahap 5: Perhitungan nilai total dengan rumus $\mathrm{Fa}=\mathrm{w} 1 \mathrm{c} 1+$ $\mathrm{w} 2 \mathrm{c} 2+\ldots+$ wncn.

Lokasi penelitian dilaksanakan di kawasan konservasi pesisir pantai penyu Pangumbahan, lihat Gbr 2 Lokasi penelitian.

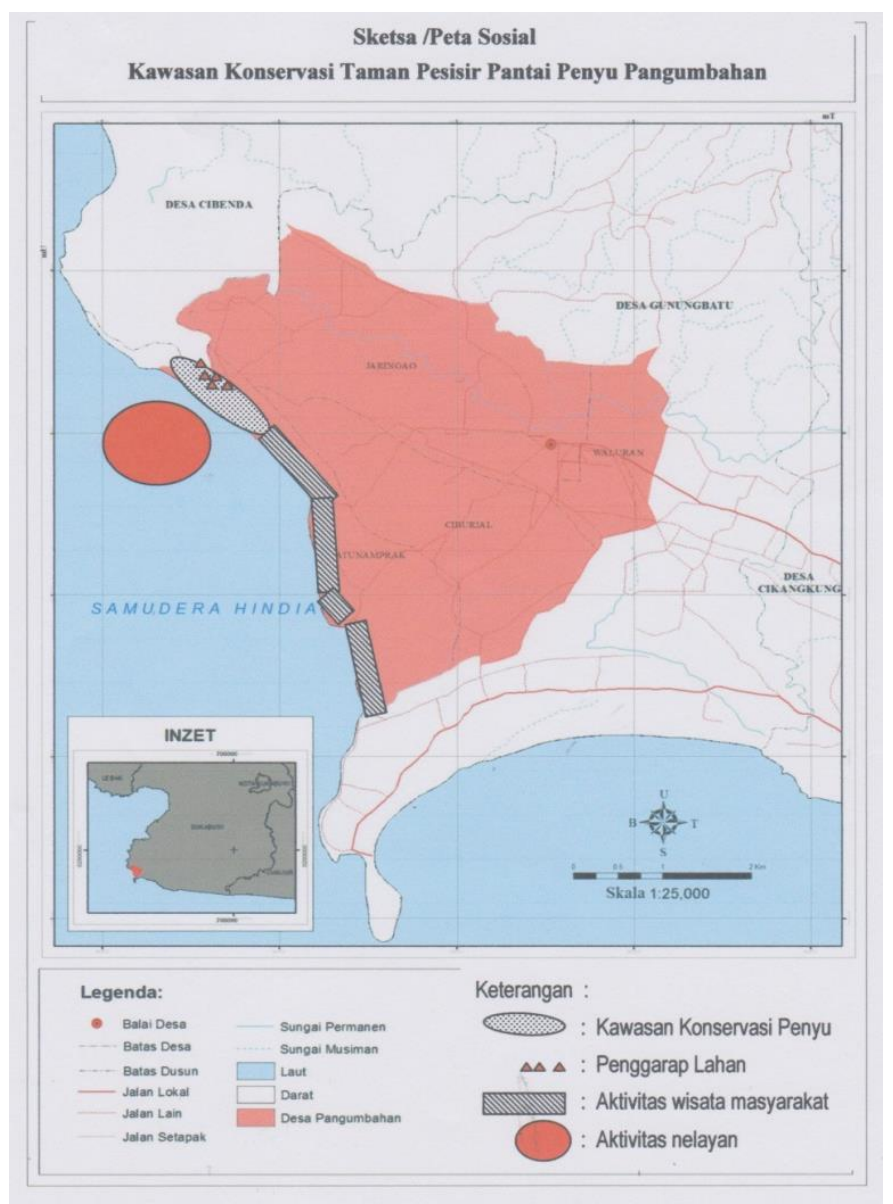

Gbr. 2 Lokasi Penelitian

\section{HASIL DAN PEMBAHASAN}

Tahap analisa pengembangan sistem informasi Konservasi penyu dijabarkan dalam dua bagian, spesifikasi kebutuhan sistem dan tampilan antarmuka pengguna. Spesifikasi Kebutuhan Sistem Sistem informasi konservasi penyu pantai pangumbahan digunakan sebagai media pelaporan jumlah penyu mendarat, jumlah telur hingga telur yang menetas dan menjadi tukik yang siap dikonservasi kembali ke alam. Petugas konservasi menginput data pada aplikasi berbasis mobile.
Pelaporan dapat dengan mudah dilihat dan dicetak pada sistem berbasis website dengan url http://sipenyu.id. Berikut ini spesifikasi kebutuhan (system requirement) dari sipenyu:

A1. Petugas dapat menginput jumlah penyu beretelur setiap pos setiap hari

A2. Petugas dapat mengelola data pribadi

B1. Admin dapat mengelola halaman laporan telur penyu

B2. Admin dapat menginput data petugas. Antarmuka Pengguna

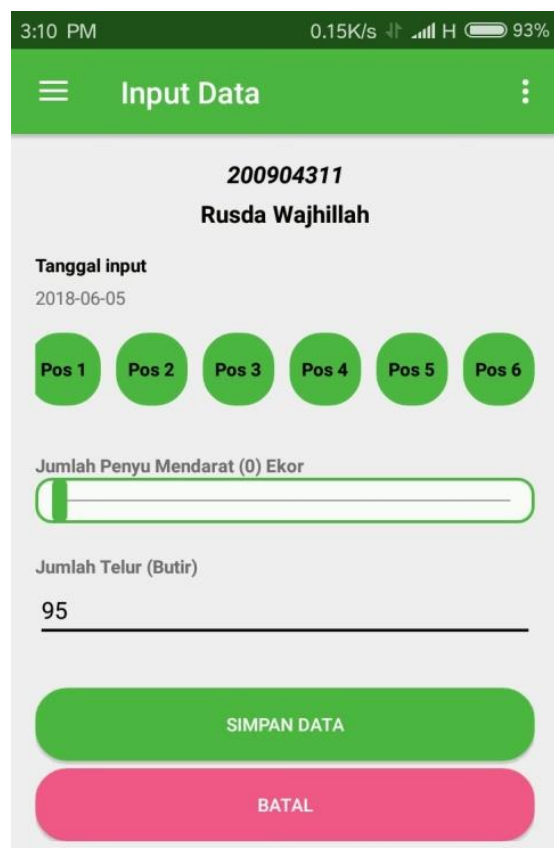

Gbr. 3 Antarmuka input telur penyu oleh petugas (A1)

Gbr 3. Menunjukkan tampilan antarmuka pengguna (petugas konservasi). Antarmuka ini dijalankan pada sistem operasi Android di Handphone petugas. Antarmuka ini didesain dengan pengunaan keyboard virtual minimum untuk menimimalisir kesalahan input dan memudahkan petugas dalam memasukkan data penyu.

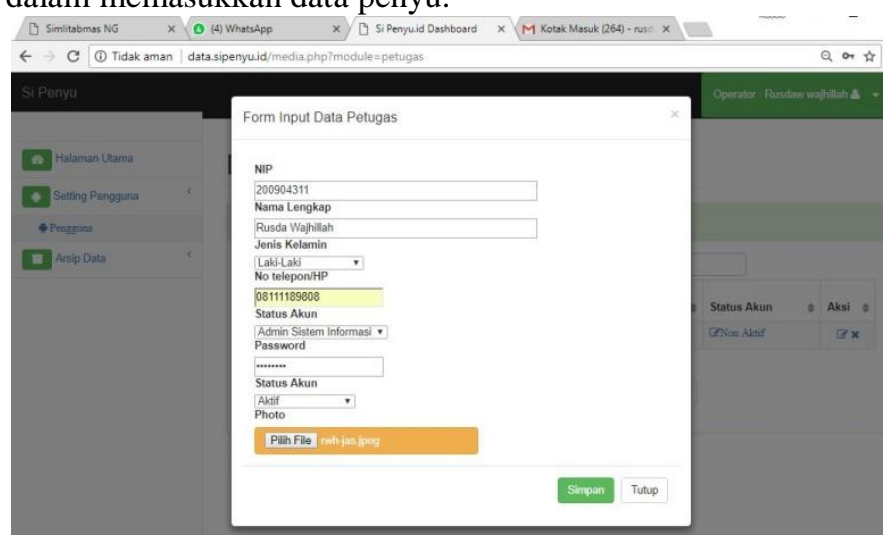

Gbr. 3 Data pribadi petugas (A2 \& B2) 
Gbr 4. Menunjukkan antarmuka untuk input dan pengelolaan petugas, pada antarmuka ini memuat NIP, Nama, Jenis kelamin(Sex), No Telepon, Level akun, Password, Status akun dan unggah photo profil petugas. Antarmuka digunakan untuk memenuhi kebutuhan sistem poin A2 dan B2.

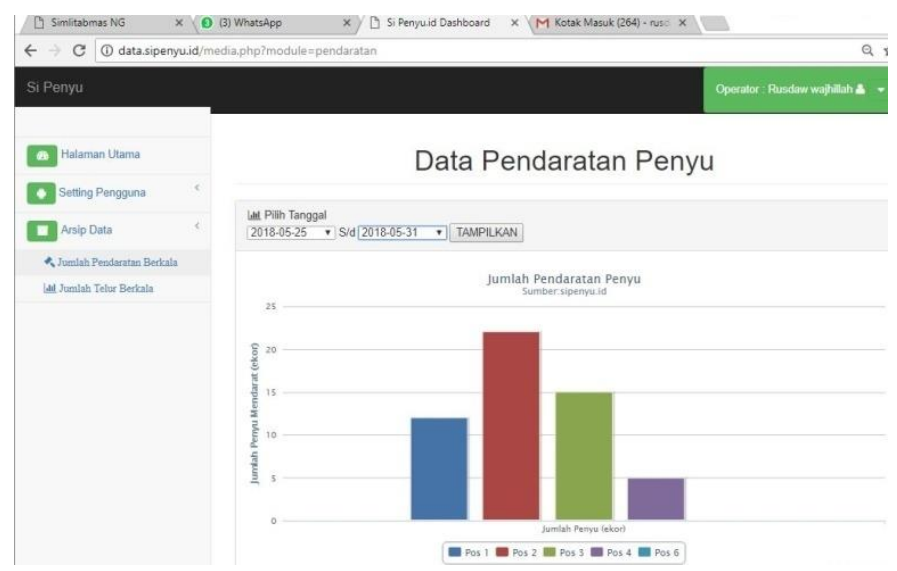

(a)

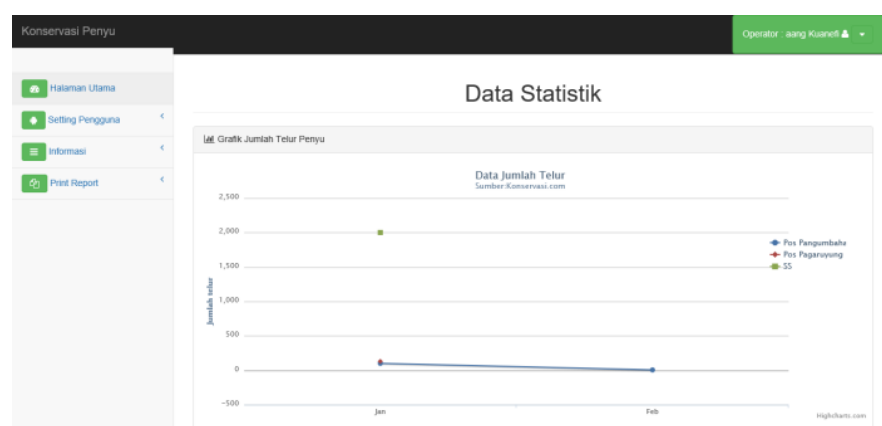

(b)

Gbr. 5 Halaman laporan telur penyu (A1)

Gbr 5 merupakan contoh capture screen untuk antarmuka pelaporan, disini pelaporan dibagi menjadi dua yaitu pelaporan pendaratan dan jumlah telur. Tampilan dari setiap laporan yang disajikan adalah hasil rentang waktu pilihan pengguna.

COBIT Domain MaE pada COBIT sangat berkaitan erat dengan pengukuran kualitas perangkat lunak. Pengukuran kualitas perangkat lunak didasarkan pada 11 faktor penentu kualitas perangkat lunak yang dapat dijadikan sebagai acuan. Data penelitian yang digunakan untuk mengukur kualitas perangkat lunak sipenyu menggunakan teknik sampling yang diambil dari 14 responden dengan pembagian: (1) responden yang cukup paham IT dan (2) responden yang kurang paham IT. Jumlah responden untuk aplikasi pelaporan penyu diambil dari seluruh pengawas di enam pos pengawasan dan tenaga staf administrasi balai yaitu 14 responden.
Hasil pengukuran terhadap kualitas perangkat lunak sipenyu dapat dilihat pada Tabel II Kualitas Perangkat Lunak Sipenyu

TABEL III

KUALITAS PERANGKAT LUNAK SIPENYU

\begin{tabular}{rlcccc}
\hline No. & $\begin{array}{c}\text { Software } \\
\text { Quality } \\
\text { Criteria }\end{array}$ & $\begin{array}{c}\text { Wi } \\
(\mathbf{0 - 1})\end{array}$ & $\begin{array}{c}\text { C_App } \\
(\mathbf{0 - 1 0})\end{array}$ & $\begin{array}{c}\text { W- } \\
\text { Web } \\
(\mathbf{1 -} \\
\mathbf{1 0})\end{array}$ & $\begin{array}{c}\text { Total } \\
\text { Nilai }\end{array}$ \\
\hline $\mathbf{1}$ & Correctness & 0.8 & 7 & 9 & 8 \\
$\mathbf{2}$ & Reliability & 0.4 & 8 & 8 & 4 \\
$\mathbf{3}$ & Efficiency & 0.2 & 7 & 7 & 2 \\
$\mathbf{4}$ & Integrity & 0.4 & 8 & 8 & 4 \\
$\mathbf{5}$ & Usability & 0.2 & 8 & 6 & 2 \\
$\mathbf{6}$ & Maintainability & 0.4 & 6 & 8 & 4 \\
$\mathbf{7}$ & Testability & 0.7 & 8 & 8 & 7 \\
$\mathbf{8}$ & Flexibility & 0.4 & 5 & 7 & 4 \\
$\mathbf{9}$ & Portability & 0.2 & 5 & 6 & 2 \\
$\mathbf{1 0}$ & Reusability & 0.2 & 6 & 6 & 2 \\
$\mathbf{1 1}$ & Interoperability & 0.2 & 7 & 8 & 2 \\
\hline & Nilai Total & & 28.6 & 31.8 & 41 \\
\hline
\end{tabular}

Menggunakan rumus (1) software quality factor (Fa) untuk web sipenyu dihitung sebagai berikut:

$\mathrm{Fa} \_$Web $=(7 * 0.8)+(8 * 0.4)+(7 * 0.2)+(8 * 0.4)+(8 * 0.2)+$ $(6 * 0.4)+(8 * 0.7)+(5 * 0.4)+(5 * 0.2)+(6 * 0.2)+(7 * 0.2)$

$=5.6+3.2+1.4+3.2+1.6+2.4+5.6+2+1+1.2+1.4$

$=28.6$

Perhitungan Fa Applikasi $=(9 * 0.8)+(8 * 4)+(7 * 0.2)+(8 * 0.4)$ $+(6 * 0.2)+(8 * 0.4)+(8 * 0.7)+(7 * 0.4)+(6 * 0.2)+(6 * 0.2)+$ $(8 * 0.2)$

$=7.2+3.2+1.4+3.2+1.2+3.2+5.6+2.8+1.2+1.2+$ 1.6

$=31.8$ 


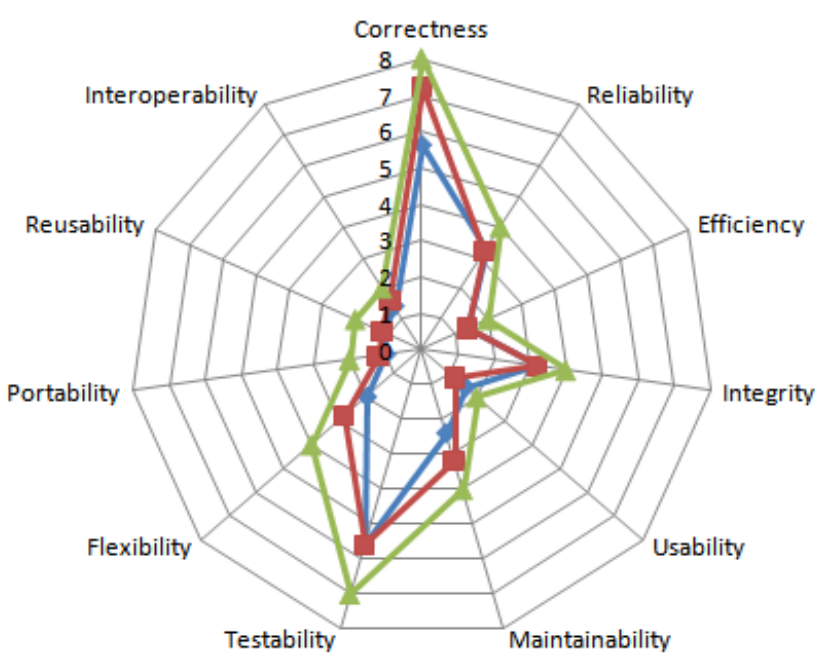

Gbr. 6 Grafik Radar nilai kualitas perangkat lunak sipenyu

Data hasil pengolahan nilai kuesiner dapat disimpulkan bahwa nilai bobot aplikasi android sipenyu lebih unggul 3.2 poin (31.8-21.6) dan selisih nilai 21.4 poin dari total nilai dari keseluruhan faktor penilaian kualitas perangkat lunak.

\section{SIMPULAN}

Penelitian ini merupakan penerapan teknologi informasi ke dalam sistem informasi pengawasan dan konservasi penyu di Kabupaten Sukabumi. Sistem informasi yang dibangun didasarkan pada kebutuhan pengguna dan perkembangan teknologi saat ini. Manfaat secara langsung yang dapat diperoleh dari penelitian ini adalah kemudahan petugas konservasi dalam menginput data penyu yang mendarat dan penyu yang bertelur.Data dapat diinput setiap hari oleh masing-masing petugas pos sesuai dengan kondisi sebenarnya..

\section{UCAPAN TERIMA KASIH}

Terima kasih dan apresiasi yang sebesar-besarnya kami ucapkan kepada Direktorat Jenderal Risbang - Kementerian Riset, Teknologi dan Pendidikan Tinggi (Ristekdikti), atas pendanaan penelitian ini.

\section{REFERENSI}

[1] Pesisir dan Pulau-pulau Kecil Direktorat Konservasi dan Taman Nasional Laut, "Pedoman Teknis Pengelolaan Konservasi Penyu," Jakarta, 2009.

[2] Dinas Kelautan dan Perikanan Kabupaten Sukabumi, "Selayang Pandang Konservasi Penyu Taman Pesisir Pantai Pangumbahan," Kabupaten Sukabumi, 2016.

[3] Kementerian Lingkungan Hidup - Republik Indonesia. Kementerian Lingkungan Hidup Republik Indonesia. [Online]. http://www.menlh.go.id/pengelolaan-penyu-di-indonesia/

[4] Jogiyanto Hartono Mustakini, Analisa dan Desain Sistem Informasi Pendekatan. Terstruktur Teori dan Praktik Aplikasi Bisnis. Yogyakarta, Indonesia: ANDI, 2005.

[5] IEEE, "IEEE Standard Glossary of Software Engineering Technology," Institute of Electrical and Electronics Engineers, New York, IEEE Std
610.12-1990 1990.

[6] P.K. Richards, G.F. Walters J.A. McCall, "Factors in Software Quality," US Department of Commerce, Tehnical Report RADC-TR-77-369 1977.

[7] G. W. T.P. Bowen, Spesification of Software Quality Attributes: Software Quality Evaluation Guidebook. New York: Griffis Air Force Base, 1985. 